\title{
Kernos
}

Revue internationale et pluridisciplinaire de religion grecque antique

$26 \mid 2013$

Varia

\section{Amy C. Smith, Polis and Personnification in Classical Athenian Art}

Joannis Mylonopoulos

\section{(2) OpenEdition \\ Journals}

Electronic version

URL: http://journals.openedition.org/kernos/2145

DOI: 10.4000/kernos.2145

ISSN: 2034-7871

\section{Publisher}

Centre international d'étude de la religion grecque antique

Printed version

Date of publication: 10 October 2013

Number of pages: 391-396

ISSN: 0776-3824

\section{Electronic reference}

Joannis Mylonopoulos, "Amy C. Smith, Polis and Personnification in Classical Athenian Art", Kernos

[Online], 26 | 2013, Online since 10 October 2013, connection on 02 March 2021. URL: http:// journals.openedition.org/kernos/2145 ; DOI: https://doi.org/10.4000/kernos.2145

This text was automatically generated on 2 March 2021.

Kernos 


\title{
Amy C. Smith, Polis and Personnification in Classical Athenian Art
}

\author{
Joannis Mylonopoulos
}

\section{REFERENCES}

Amy C. Smith, Polis and Personnification in Classical Athenian Art, Leiden/Boston, Brill, 2011. 1 vol. $22 \times 29$ cm, xlv+202 p., 32 pl. (Monumenta Graeca et Romana, 19). ISBN :

978-90-04-19417-5.

1 The present study originates in the A.'s 1997 doctoral dissertation at Yale University and is the latest in a series of monographs and edited volumes dedicated to personifications in the ancient Greek world. ${ }^{1}$ It consists of twelve occasionally far too brief chapters, a catalogue, and seven indices. Thirty-two black-and-white plates with 100 figures showing mostly vases, but also two statues, two statue bases, one altar, and fifteen votive and document reliefs complete the work. Bibliographic references, including publications up to 2010, and a list of abbreviations precede the text.

2 Chapter One (Introduction: Viewing personifications in Classical Athens, p. 1-10) opens with a short presentation of the famous hydria by the Meidias Painter in London (BM 1772.3-20.30*) on which the abduction of the Leukippides is rendered. On the vase, the personified Persuasion (Peitho) and Health (Hygieia) are depicted among various heroic and divine figures. S. poses a series of important questions pertaining to the use of personifications in general and to their meaning in the particular iconographic context of the given vase. The hydria in London serves as a starting point for S.'s definition of (civic) personifications, which are understood as representations of abstractions, things, or places in human form "that benefited the community as a whole" and were at least occasionally - worshipped in Athens. The A.'s declared aim is to determine what exactly the use of personifications with political implications in Athens' visual 
arts can tell us about the polis itself. Chronologically, S. chooses to concentrate on 'democratic' Athens from 480 to $323 \mathrm{BCE}$. It is perhaps due to the introductory nature of the chapter that we are left wondering what is political or civic about the presence of Hygieia and Peitho on the London hydria. S.'s understanding and chronological framing of the qualitative terms 'political' and 'civic' follows the traditional scholarly opinion that Athenian art became "increasingly political" in the Classical period. In my view, this opinion is based on a misunderstanding of political or civic art of the Archaic period, generated in part through an overemphasis on the alleged connection between the institution of democracy and the rise of political art in Athens. Before concluding the chapter with a synopsis of the entire book, S. presents a brief but nonetheless useful overview of previous scholarship on personifications.

3 In Chapter Two (Names or comments? The birth of political personification in Greece, p. 11-26), one of the main weaknesses of the book's structure becomes manifest: issues that do not clearly belong together are discussed in subchapters, so that questions about terminology are addressed alongside the cultic nature of personifications, their presence in Old Comedy and Early Classical art in Athens, and the labelling of personifications in vase painting. After highlighting the absence of an ancient equivalent to the term "personification," the A. proceeds with a short discussion of the words prosopopoiia, allegoria, and hyponoia, as well as of their use in ancient sources and modern scholarship. S. treats the phenomenon of the deification of abstract ideas and situates their personification in the context of mythological narratives in far too summary a manner. I will have to disagree with the A.'s claim that whether or not a personification was also a recipient of cult "is generally irrelevant to the question of how Classical Athenian artists used personifications." In my view, understanding the intellectual processes behind the transformation of specific personifications into divine entities with their own cults (Eirene is perhaps one of the most prominent examples) is of paramount importance. In many instances, this transformation originated in a particular political context, a point which renders the A.'s aforementioned statement all the more puzzling in light of her interest in the political implications of personifications. After referring to the works of Homer and Hesiod, S. addresses the use of personifications in Archaic art, suggesting that in this period they "were largely confined to traditional mythic scenes" and "rarely shown in political contexts before the Classical period." The latter statement recalls the aporia of the political nature of the hydria by the Meidias Painter, with which the A. chose to commence her study. S. then moves to an overview of personifications in lyric poetry, drama, and old Comedy. She observes strong similarities between Old Comedy and visual arts in their use of personifications, which she attributes to poets' and artists' common interest in contemporary culture. Even though I am not entirely in agreement (were tragedians less interested in politics?), the A. could have pressed this point further and analysed it in more depth. As it stands, the reader is left with a rather overgeneralized statement. Following an examination of personified abstract concepts, such as Nike, Peitho, Ananke, and $\mathrm{Bia}^{2}$ as symbolic figures, $\mathrm{S}$. dedicates the last part of the chapter to the use of labels ${ }^{3}$ for personifications in art. Here, the A. discusses in the span of just three pages far too many debated issues, among them the use of attributes in Greek art, ${ }^{4}$ literacy in ancient Greece, and the notions of public and private culture in antiquity.

4 Chapter Three (Humanising Greek places and spaces: Local personifications and Athenian imperialism, p. 27-39) explores a fascinating phenomenon, the personification of localities, with a focus on the sons and daughters of Okeanos, the Nereids, and 
eponymous heroines of islands and cities. With respect to the family of Okeanos, S. traces a tendency away from semi-theriomorphic representations toward humanised ones. ${ }^{5}$ The omission of Acheloos ${ }^{6}$ and other representations of rivers - the latter found especially on coins minted by the Greek colonies in Southern Italy and Sicily - is rather puzzling. Personified rivers never lost their association with the bull, although most of them appear as young men with horns (see the representation of Kephisos on the famous relief of Xenokrateia in the National Museum, Athens, inv. no. 2756), in contrast to the bull-bodied Acheloos. S. is certainly correct to claim that the personifications of fountains and springs - in the vast majority female - assume a human form. ${ }^{7}$ She is also right in suggesting, with respect to the daughters of Asopos, that the appearance of personifications of Aigina, Nemea, Thebe, and Salamis in Athenian art was politically motivated. The same applies to the personifications of Eleusis, Delos, Euboia, and Lemnos, whereas, in my view, political motivation does not really account for the use of the personified demos of Melite. In the final section of the chapter, S. addresses an extremely complex issue: the possible conflation of maenads, Nymphs, and Nereids. The brevity of this discussion does not do justice to the subject, however, and the reader is left wondering about its pertinence to the topic of personified localities. ${ }^{8}$

Chapter Four (Goddess before personification? Right and retribution, p. 41-49) is devoted to Nemesis and Themis. After a short introduction to the well-known problems confronting a clear-cut definition of the ancient terms nemesis and themis, S. discusses Nemesis' various and often contradictory myths, especially the versions connecting her to Helen. Helen's relation to Nemesis plays a significant role in the A.'s understanding of the goddess' statue in Rhamnous, which is paralleled by a scene (Helen's abduction) on a small amphora in Berlin and by Kratinos' lost play Nemesis. Although S. accepts the traditional view that emphasizes Helen's presence in Rhamnous, she then interprets the apple branch in the (cult) statue's hand as an attribute that reveals the goddess' character as a chthonic or nature divinity. I prefer B. Knittlmayer's view, according to which the apple branch refers to Aphrodite and thus ultimately to Paris' judgement, Helen, and the Trojan War. In the part focusing on Themis, S. examines the goddess' connection to $\mathrm{Ge}$ and suggests that "Delphic and Rhamnousian elements are incorporated into Themis' iconography in Athens." To support this hypothesis, S. adduces the well-known tondo of the Kodros Painter's cup in Berlin, which shows Themis in the form of the Delphic Pythia. According to S., the apple branch and the phiale in Themis' hands derive from the way in which the Rhamnousian Nemesis was visualized. While the Delphic iconographic elements of the scene are patently discernible, following the traditional dating of the statue in Rhamnous and of the cup in Berlin, one should reverse S.'s hypothesis and speculate that the image of the Rhamnousian Nemesis was influenced by pre-existent Attic visual traditions associated with Themis. Ultimately, I think that the connection drawn between the statue at Rhamnous and the cup by the Kodros Painter is rather forced. The interpretation of the phiale that both Themis and Nemesis can hold as an attribute indicating their "righteousness, particularly in the religious sphere," seems too narrow; after all, Nemesis and Themis are only two from a relatively large group of deities (e.g. Nike and Hera) depicted in the act of libation.

6 In the introduction to Chapter Five (The independence of epithets: Kharites, virtues, and other nymphs in the 'gardens of Aphrodite', p. 51-69), which focuses on personifications associated with Aphrodite, S. is absolutely right to stress that personified virtues such as Eudaimonia, Eutychia, and Harmonia cannot be reduced to either their civic or 
personal qualities. The exclusion of Eros from this chapter, due to the A.'s view that Love/Eros is neither political nor civic, is certainly debateable. After brief encounters with Philia, Arete, and Harmonia, S. concentrates on Hygieia. Here, I am not quite sure whether I understand S.'s statement that Hygieia "does not bear any particular political connotations" when she is worshipped and represented alongside Asklepios. How does the connection between Asklepios and Hygieia differ from the association of the latter with Athena and/or Aphrodite? In the subchapter addressing Peitho (one of the longer ones in the book), S. manages to explicate convincingly the double nature of Peitho, which had not only erotic but also prominent political connotations, especially thanks to this personification's connection with Aphrodite Pandemos. After a cursory discussion of Harmonia, S. turns her attention to Eudaimonia, Eutychia, and Paidia. Although the A. argues the civic nature of the first two personifications with clarity, the inclusion of Paidia among the political virtues, since it helped to recall "the pleasures enjoyed by individuals in a civilized polis," seems rather strained. The chapter concludes with an overview highlighting the association of the aforementioned personifications with Aphrodite in her dual role as "a civic protector and a patron of erotic love." On this point, S. suggests that, even if not labelled explicitly as Pandemos in vase painting, ${ }^{9}$ this is how Athenians would have seen Aphrodite whenever she was represented amidst these personifications.

7 Chapter Six (Aristocracy or democracy? Eukleia and Eunomia between the gods, p. 71-76) focuses on Eukleia and Eunomia, two personifications worshipped in Athens from the early fifth and fourth centuries, respectively. They appear together in vase painting in the last two decades of the fifth century, often in association with Aphrodite. S. discusses the presence of the two personifications in literary sources and visual arts, before concentrating on the question whether or not Eukleia and Eunomia shared a sanctuary before the Roman Imperial period. ${ }^{10}$ Unfortunately, the A. offers no clear answer to this intriguing matter.

Chapter Seven (Visual personifications in literature and art: Aristophanes' Eirene and her attendants, p. 77-81) opens with a short but nevertheless convincing analysis of Eirene's connection with Opora. The A. is certainly right to place an emphasis on the agricultural aspects of Eirene's conceptualization in fifth-century Athens. Yet, in discussing Opora and Theoria as attendants of Eirene, S. remains too general in her analysis, when, for example, she states that Theoria was "also political insofar as she is relevant to democratic institutions."

9 Chapter Eight (Ephemeral personifications: Civic festivals and other peacetime pleasures, p. 83-89) explores what the A. calls "ephemeral" personifications, a term that the A. does not explain. It seems as if S. considers personifications of festivals or festivalrelated activities, such as Pompe, to be "ephemeral"; however, Basileia and Soteria (the latter is not associated with the fourth-century festival) do not fit this concept. In addition, one wonders why the personification of Theoria is treated in the previous chapter and not together with Pompe, Pandaisia, and Pannychis, since these are all related to religious activities. Although there are no figures in Athenian vase painting that can be securely identified as personifications of Pan-Hellenic festivals, ${ }^{11}$ there is literary evidence for two paintings that depicted Alkibiades with the personified Nemean, Delphic, and Olympic games. While the political message of Alkibiades' paintings is obvious, one may still wonder what exactly makes the personified Pan- 
Hellenic games per se political, apart from the generally civic nature of every Greek festival.

In Chapter Nine (Masculine people in feminine places: The body politic at home and abroad, p. 91-107), personifications of political institutions and bodies, such as the Boule or the Demos, are brought together with those of cities or regions, such as Messene, Epidauros, or Peloponnesos. At the outset of the chapter, S. rightly asserts that scholarship has far too often confused personification with deification. Yet, I fail to follow the A.'s rigid claim that "personification is a form of expression whereas deification is a form of belief." Basing her argument on the cult of the personified Megalopolis (Paus. 8.30.10), S. convincingly challenges the idea that the deification of personified cities emerges only in the Hellenistic period. In her brief discussion of the so-called Tyche of Antiocheia, however, the A. seems to ignore the latest magisterial study of the subject by M. Meyer. ${ }^{12}$ Although the city of Athens was never personified, the Athenian Demos was often depicted on so-called document reliefs. In this context, S. discusses the rather problematic cases of images of the personified Attica as well as of possible representations of Phyle in the form of a wingless 'Nike.' The A. stresses throughout this subchapter that none of these figures was labelled and all identifications remain hypothetical (and in my view very much so). The largest part of the chapter deals with the personification of the Athenian Demos in literary sources and visual media, especially on document reliefs, a subject studied extensively by M. Meyer and C. Lawton. ${ }^{13}$ In the final part of the chapter, S. focuses on the personifications of cities outside Attica and regions other than Attica. Although S. discusses eponymous heroes in the subchapter dedicated to the Athenian tribes, one cannot but wish that she had addressed the widespread phenomenon of the "creation" of eponymous heroes for a city (for example, Nauplios for Nauplion) as a possible and, based on our evidence, certainly more attractive alternative to the personification of a city.

11 After a brief introduction to the historical events of the first three decades of the fourth century BCE, Chapter Ten (The mother of wealth: Eirene revisited, p. 109-118) focuses on Kephisodotos' statue of Eirene and the personification of Ploutos. Even though the A. ignores M. Meyer's recent article, ${ }^{14}$ the part concerning the statue that originally stood on the Athenian Agora offers a helpful overview of earlier scholarship on the subject but no new insights into the iconography of the statue. Instead, most of the chapter is dedicated to Ploutos, his connections with Eleusis and the Eleusinian deities, as well as his iconography as a child in the visual arts and as an older blind man in literary sources.

12 A substantial part of Chapter Eleven (From oikos to polis: Democracy and more civic virtues in fourth century Athens, p. 119-126) concentrates on Tyche, and specifically on Agathe Tyche. S. primarily discusses Tyche's cult in Athens, since this personification seems not to have been depicted on vases or reliefs in the Classical period. Although it is not entirely clear, S. seems to be sceptical about the assumption of a cult of Tyche on the Athenian Agora, like those of Eleos, Aidos, ${ }^{15}$ Pheme, and Horme. I am not convinced that the Agathe Theos found on two votive reliefs from Athens and Piraeus is an "alter ego of Agathe Tyche," as S. proposes. In her analysis of the rarely - if ever - depicted Philia, the A. identifies a maenad under the name Philia on a bell krater in Vienna (KHM IV 1772) as the personification of friendship. Although an admittedly complex subject, one should reconsider whether or not maenads bearing names associated with 
virtues ought to be identified as personifications, as S. seems to suggest (following R. Osborne). The questions pertaining to the cult of Homonoia in Athens and her presence in the visual arts are indeed exceedingly complicated, and the reader is thankful that S. chooses at least to address them. Although Demokratia appears on the famous antityranny decree from the Athenian Agora (Agora I 6524), most of the material evidence associated with the personified democracy is lost and known only through later literary sources.

13 In Chapter Twelve (Conclusion, p. 127-131), S. presents a summary of the previous chapters' contents. The study closes with a catalogue (p.133-176) containing 49 document reliefs, 8 monumental paintings, 11 votive reliefs and statue bases, 16 statues, and 72 vases. Each group is arranged in roughly chronological order. The individual entries are concise but nevertheless very informative. The seven separate indices (p. 177-202) are extremely helpful. Although the reader will appreciate how richly illustrated the volume is, the photographs are often too small.

Studying a phenomenon that has attracted the attention of a large number of scholars is always a difficult task; one must define precisely which gap in scholarship the new study is supposed to close. The present volume wishes to remedy a gap in our understanding of the civic/political nature of personified virtues in Classical and Late Classical Athens. Compared to W. Messerschmidt's study of personified political institutions and values, the A. takes a broader approach, which is more than welcome. Yet, S.'s definition of civic/political becomes so broad that it could potentially incorporate everything, and at times it does (e.g. Paidia). The structure of the book and the rather inexplicable brevity of several chapters dampen the clarity of the argument that the A. is trying to make. For example, personified localities are discussed in Chapters Three and Nine, Eirene in Chapters Seven and Ten, personified religious activities, such as Theoria, in Chapter Seven, while the analysis of personifications, such as Pompe, is found in Chapter Eight. The general structure seems at times thematic, and at others chronological. In addition, the reader repeatedly encounters overgeneralized statements and imprecisely defined terms that distort the fact that the A. has indeed identified a gap in scholarship. We do need to broaden our perspective of the civic/political background, use, and abuse of personifications, and S.'s study is certainly a first step in this direction.

\section{NOTES}

1. I mention (in chronological order) only H.A. Shapiro, Personifications in Greek art. The representation of abstract concepts 600 - 400 B.C., Kilchberg/Zurich, 1993; E. Stafford, Worshipping virtues. Personification and the divine in ancient Greece, London, 2000; B. Borg, Der Logos des Mythos. Allegorien und Personifikationen in der frühen griechischen Kunst, Munich, 2002; W. Messerschmidt, Prosopopoiia. Personifikationen politischen Charakters in spätklassischer und hellenistischer Kunst, Cologne, 2003; E. Stafford (ed.), Personification in the Greek world. From antiquity to Byzantium, Aldershot, 2005. 
2. The A. addresses Bia as "a masculine deity" (p. 20), although both the name and the few existing representations clearly identify Bia as a female personification.

3. In this context, the reference to the alleged Modern Greek tradition of naming especially daughters after virtues (Eirene, Sophia) is as unnecessary as it is wrong. In Northern Europe, girls are named 'Ursula' after the saint and not because the parents 'remember' that the name means "little she-bear."

4. On the use of attributes, see most recently J. Mylonopoulos, "Odysseus with a trident? - The use of attributes in ancient Greek imagery," in id. (ed.), Divine Images and Human Imaginations in Ancient Greece and Rome, Religions in the Graeco-Roman World, Leiden, 2010, p. 171-203.

5. E. Aston, Mixanthrôpoi. Animal-human hybrid deities in Greek religion, Liège, 2011. The volume was published in the same year as S.'s study, which explains its omission.

6. H.P. Isler, Acheloos. Eine Monographie, Bern, 1970.

7. It is interesting that female monsters, such as Medusa, the Sirens, Skylla, or the Sphinx, can assume semi-theriomorphic forms, while female representations of localities, as opposed to their male counterparts (rivers), are humanised.

8. The overgeneralized characterisations of maenads as references to the "uninhibited world of Dionysos" and of Nereids as allusions to "seafaring" are not sufficient to associate these entities with those personifying specific localities, such as those discussed previously in the chapter.

9. The A. speculates that the epithet Pandemos was omitted because it was perhaps "laboriously long." To the best of my knowledge, in vase painting the gods' names are never accompanied by epithets.

10. Among the inscriptions cited by S. as evidence for a joint sanctuary, IG $\mathrm{II}^{2} 3738$ and 4193 refer to a priest responsible for the cults of Eukleia and Eunomia, while $I G \mathrm{II}^{2} 2776$ contains noreference to the two personifications. S. fails to mention IG $\mathrm{II}^{2} 1035$ (last decade of the first cent. BCE), which explicitly refers to a sanctuary that Eukleia and Eunomia shared.

11. S. is certainly right in emphasizing that one should not confuse the personified site where a festival took place with the festival itself.

12. M. Meyer, Die Personifikation der Stadt Antiocheia. Ein neues Bild für eine neue Gottheit, Berlin, 2006.

13. The A. cites both authors' studies, but seems to rely primarily on C. Lawton's work.

14. M. Meyer, "Das Bild des 'Friedens' im Athen des 4. Jhs. v. Chr. Sehnsucht, Hoffnung und Versprechen," in ead. (ed.), Friede - Eine Spurensuche, Vienna, 2008, p. 61-85.

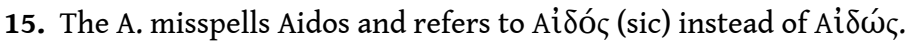

\section{AUTHORS}

\section{JOANNIS MYLONOPOULOS}

Columbia University 